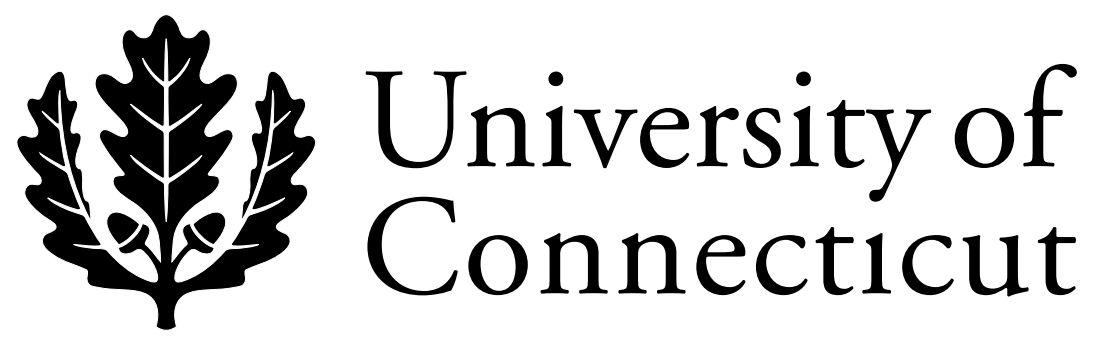

Department of Economics Working Paper Series

\title{
Knowledge, Consumption, and Endogenous Growth
}

Richard N. Langlois

University of Connecticut

Working Paper 2000-02

January 2000

341 Mansfield Road, Unit 1063

Storrs, CT 06269-1063

Phone: (860) 486-3022

Fax: (860) 486-4463

http://www.econ.uconn.edu/ 


\section{Introduction.}

The recent efflorescence of interest in "endogenous" theories of economic growth has focused attention on the nature and role of knowledge in the growth process (Romer 1986, 1990; Grossman and Helpman 1990, 1994). Unlike earlier models of growth (Solow 1956; Swan 1956) in which technological change appeared as an exogenous parameter, this New Growth Theory (NGT) has sought to "endogenize" technical change by folding its production more fully into the neoclassical positive heuristic. Knowledge no longer appears as manna from heaven, but is now produced just as are bananas and tires: as the result of the rational optimizing behavior of economic agents. ${ }^{1}$ These agents invest resources in Research and Development (R\&D), a sausage machine whose output is new technological knowledge. For reasons that Kenneth Arrow (1962) long ago articulated, however, the good called knowledge has certain peculiar properties in that, once created, it can spill easily into the hands of others at zero marginal cost. ${ }^{2}$ This process of spillover (and the nonconvexity it implies) is the source of the increasing returns that generate economic growth.

While not questioning some essential truth to this story, students of the process of technological change - especially those who have not restricted themselves to theoretical models - have expressed considerable doubt about the this

1 It thus strikes me as somewhat incongruous that proponents of the N ew Growth Theory refer to the older Solow-Swan approach as "Neoclassical" Growth Theory, implying that the NGT is somehow not neoclassical. By the accepted criteria of the philosophy of science, it is the other way around. For a more general critique of the NGT see Langlois and Robertson (1996).

2 To be precise, knowledge is nonrival and (only) partially excludable (Romer 1990, p. S74). 
picture of technological knowledge and its creation. Those who study the historical processes of technical change have found that knowledge does not always - and perhaps does not usually - take the form Arrow assumed (Nelson 1992). Much technological knowledge cannot in fact be transmitted easily to others; much technological knowledge is inarticulate and tacit (Polanyi 1958), and can be transmitted only at a cost through imitation and apprenticeship. This observation creates a difficulty for knowledge-based theories of growth. To the extent that knowledge is tacit in this way, it behaves like an ordinary private good, and its role in generating increasing returns is lost.

One response to the problem of tacit knowledge among sophisticated students of innovation has been to create a clear distinction between knowledge that is tacit and knowledge that is codified. Codified knowledge is knowledge that has been (or can be) converted into symbols for easy transmission, replication, and storage (Boisot 1995; Saviotti 1998). Such knowledge thus partakes of Arrovian public-good properties, which makes it a potential source of increasing returns. Under this stratagem, the large place of tacit knowledge in social learning does not invalidate growth theory so long as there also exists codified knowledge in suitable quantities. Some writers would even go further, suggesting that technological change and economic growth have had the effect of tipping the balance between tacit and codified knowledge (Arora and Gambardella 1994; Cowan and Foray 1997). "More" 
knowledge is becoming codified, implying (and perhaps explaining) an accelerated pace of social learning and economic growth.

This essay takes a more skeptical view of the proposition that we are experiencing greater codification hand in hand with modern technology and economic growth. But such skepticism need not have dire implications for (the theory of) economic growth. The essay will take an equally skeptical view of the proposition that only codified knowledge, and never tacit knowledge, can generate economic growth.

\section{Know ledge as structure.}

Part of the difficulty in understanding the economics of knowledge is that the literature is filled with cross-cutting and often mutually inconsistent distinctions and definitions: tacit versus explicit or codified knowledge; general versus localized knowledge; abstract versus concrete knowledge - and even the hoary distinction between knowledge and information. This essay may not sort out these tangles, and may even make matters worse. But it is arguably useful to begin with some attention to what one means by knowledge.

Knowledge is a peculiar commodity in ways that go well beyond its (sometime) public-good character. At base, knowledge is always structure. It is therefore an inherently qualitative concept. Kenneth Boulding put it this way.

[W] cannot regard knowledge as simply the accumulation of information in a stockpile, even though all messages that are received 
by the brain may leave some sort of deposit there. Knowledge must itself be regarded as a structure, a very complex and frequently quite loose pattern, ... with its parts connected in various ways by ties of varying degrees of strength. Messages are continually shot into this structure; some of them pass right through its interstices ... without effecting any perceptible change in it. Sometimes messages "stick" to the structure and become part of it. ... Occasionally, however, a message which is inconsistent with the basic pattern of the mental structure, but which is of a nature that it cannot be disbelieved hits the structure, which is then forced to undergo a complete reorganization. (Boulding 1955, pp. 103-104, quoted in Machlup 1983, p. 643n).

The association of knowledge with structure is intuitively appealing, if still rather vague. What makes a structure "knowledge"? At some level, a structure constitutes knowledge if that structure is ordered in a way that produces results. Think of genetics. We can say that DNA is a knowledge structure because it is an orderly arrangement that "knows how" to do something, namely how, in conjunction with an existing organism, to generate a new organism. That new organism in turn is also an ordered structure that does something, namely survive the evolutionary process.

Donald MacKay thinks of a system's structure as defining “conditional states of readiness" on which a signal operates. It is the overall configuration that determines the meaning — and the meaningfulness - of a message. "It isn't until we consider the range of other states of readiness, that might have been considered but weren't, that the notion of meaning comes into its own. A change in meaning implies a different selection from the range of states of readiness. A meaningless message is one that makes no selection from the range. An ambiguous message is one that could make more than one selection" (MacKay, 1969, p. 24, emphasis original). 
MacKay offers the metaphor of a railroad switching yard in which the configuration of tracks and switches stands ready to direct the trains passing through it. By sending the right electronic signal (or, in older yards, by inserting the correct key in a switch-box) one can rearrange the configuration of tracks. The meaningfulness of a message thus depends on its form - on the shape of the key. And that meaning consists in the change the message effects in the arrangement of the yard, the selection it makes from the set of all possible configurations.

But where does the structure of knowledge - the railroad switching yard come from? How does it form, and how is it modified by experience? As recent work in cognitive science is suggesting (Holland et al. 1986; Edelman 1992), human learning involves the building up of a structure of categories (of conditional states of readiness) from experience. Through a ruleguided process of sorting, new experiences are shunted into appropriate categories, and these experiences may at the same time help reinforce or change the structure. As F. A. Hayek long ago put it, "that which we call knowledge is primarily a system of rules of action assisted and modified by rules indicating equivalences or differences of various combinations of stimuli"3 (Hayek 1978, p. 41). To study the growth of knowledge is thus to study the evolution of systems of rules of action.

3 Hayek's Sensory Order (1952) arguably anticipated what is the dominant direction of thought among cognitive theorists today (Weimer 1982; Edelman 1987). 
A conceptualization of knowledge as involving rule-following systems is certainly consistent with the general understanding of tacit knowledge. Nelson and Winter (1982) have associated Polanyi's concept with the notion of routines, which they see as the basic element of human action. Routines are habitual patterns of behavior that embody skill-like knowledge. ${ }^{4}$ Such knowledge cannot be articulated or transmitted explicitly but must be acquired over time through a process of apprenticeship and trial-and-error learning. A structure of routines - in an individual, an organization, or a wider institution - is clearly a system of rules of action and a knowledge structure (Langlois 1997).

But what about codified knowledge? As Kenneth Arrow (1974, chapter 2) notes, individuals and organizations can have a particular kind of knowledge structure that is able to understand information consisting of explicit symbols. In the first instance, these symbolic transmissions are information not knowledge. They are codes that activate the rule-based categorization system of the receptor structure in a meaningful way. It is the structure, not the signal, that is knowledge; and, in general, the knowledge structure is not itself codified in an important way and may be mostly

4 Cowan and Foray (1997), however, attempt to connect routines to codified knowledge. In some cases, they write, "a procedure that was developed to produce some end becomes routinized, and repeatable, which implies that it can be broken down into component pieces, each of which is sufficiently simple that it can be described verbally, or embodied in a machine. This, again, is a process in which tacit knowledge becomes codified." Although repetition and routine may certainly lead to embodiment in machines (a point to which I return below), I do not see such embodiment as necessarily a process of codification. Nor is it obvious that repetition and replicability by themeselves lead to codification. A slam dunk is (broadly) repetitive and replicable, but no one can write a code that would fairly describe it let alone allow anyone to replicate it who had not also engaged in a lengthy process of learning-by-doing. 
tacit. ${ }^{5}$ Even though Chinese characters can be beautifully written in pen and ink, the knowledge structure necessary to read the characters has to have been built up by years of skill training.

Some writers, including Cowan and Foray (1997), seem to be making a larger claim, namely, that knowledge is increasingly becoming codified. The sense of the term "codified knowledge" must be that some of the structure itself is transformed into coded messages, which can then be decoded by others and turned back into structure. ${ }^{6}$ For example, I could transform my tacit knowledge of Chinese (if I had any) into the symbols on the page of a textbook, which others could read in order to acquire (tacit?) knowledge of the language. Since much of the mechanism of language comprehension and use is inherently ineffable, this kind of translation is

5 Recently, Cowan, David, and Foray (1999) have attacked the too-ready use of the term "tacit knowledge" in economics and policy circles, and have attempted to provide a taxonomy of types of knowledge. In their view, knowledge is either already codified or not codified. Knowledge that is not codified - and therefore "tacit" - can be uncodified either because no "codebook" has ever been created or because the codebook exists but has been "displaced," that is, the codebook is not explicit but resides in the heads of those who possess the knowledge. These authors also stress, quite rightly, the role of economic incentives in determining how much knowledge gets codified. Although I find this exercise an extremely valuable one, I remain a bit troubled by the authors's (tacit?) assumption that all knowledge is potentially codifiable, at least in principle. In my view, this misses the point of epistemological and phenomenological critics, who would insist - in opposition to some scholars of artificial intelligence in computer science - that knowledge must always retain an irreducible tacit or contextual component (Dreyfus 1979). For Cowan, David, and Foray, tacit knowledge is just knowledge not codified (but potentially codifiable). For these critics, by contrast, all knowledge is both codifiable and (inherently) non-codifiable: some parts or aspects of all knowledge can be codified, but some parts can never be codified. It is always possible in principle to create a codebook, but that codebook will never capture all the knowledge held by the individuals whose code it is.

6 There is of course no fine line between transmitting information and transmitting knoweldge, as even information may alter the structure into which it is transmitted. In fact, as Machlup points out, "[a]ny kind of experience - accidental impressions, observations, and even 'inner experience' not induced by stimuli received from the environment - may initiate cognitive 
notoriously imperfect. ${ }^{7}$ So even if we observe more codified signals in modern society, it is problematical to say that we have therefore observed more codified knowledge. And it is even more problematical to assert that we experience nowadays a greater proportion of codified to tacit knowledge. ${ }^{8}$ U lysses contains far more coded symbols than does W here the W ild Things A re; but understanding the former (if that is indeed possible) requires a far greater store of tacit knowledge than does understanding the latter.

The allure of codified knowledge stems, I believe, from the perception that codification is related to generality and abstractness. If a bit of information can be codified, that means it can be transcribed in some systematic form. System implies generality, perhaps even an understanding of abstract underlying principles. And here is the important point: knowledge that is general can be applied in many different concrete circumstances, thus spreading overheads widely and creating increasing returns.

Arora and Gambardella (1994) make an argument in the same spirit as that of Cowan and Foray, but one couched not in terms of codification but directly in terms

processes leading to changes in a person's knowledge. Thus, new knowledge can be acquired without new information being received" (Machlup 1983, p. 644, emphasis original).

7 Indeed, much of the force of a textbook actually consists not in coded representations of the knowledge sought but in injunctions to go forth and acquire tacit skills - through readings, problem sets, exercises, listening to tapes of native speakers, etc.

8 A point that Cowan and Foray acknowledge. 
of abstractness and generality. ${ }^{9}$ Technological change, they say, once rested largely on localized tacit knowledge gained from trial and error. Increasingly, however, scientists and technologists are able to distill abstract ideas and general principles from their experiments, which they can then apply successfully in other concrete circumstances. It is this (increasing) generality and abstractness that, in effect, gives rise to the $R \& D$ sausage machine of endogenous growth theory. Because abstract knowledge can be applied widely, innovation is no longer tied to trial-and-error learning in particular concrete circumstances. And individuals can increasingly specialize in the production of new knowledge, thus finally bringing to reality Adam Smith's prediction that innovation would become the business of "philosophers or men of speculation, whose trade it is, not to do any thing, but to observe every thing; and who, upon that account, are often capable of combining together the powers of the most distant and dissimilar objects"10 (Smith 1976, I.i.9, p. 21).

Much of this may be true. In my view, however, the literature praising codified, general, and abstract knowledge - and its allegedly increasing importance in modern society - misses three crucial and related points. The first is that

9 “By 'abstract' we mean the ability to represent phenomena in terms of a limited number of 'essential' elements, rather than in terms of their 'concrete' features. By 'general' we mean knowledge that relates the outcome of a particular experiment to the outcomes of other, more 'distant' experiments." (Arora and Gambardella 1994, p. 524.)

10 Of course, Smith did not view this as a prediction, but saw it as already characteristic of invention in his own day. And he was right. As H. I. Dutton (1984, especially pp. 112-117) has shown in his study of patening during the Industrial Revolution, invention was already becoming a specialized activity in Smith's day, and the process accelerated throughout the nineteenth century. The same was true of the American Industrial Revolution (Lamoreaux and Sokoloff 1999). 
generality and abstractness do not require codifiability or explicitness. ${ }^{11}$ Those of us who write about capabilities and routines are often prone to phrases like "idiosyncratic and tacit knowledge." But tacit knowledge need not in fact be idiosyncratic. Dasgupta and David (1994, p. 494) are right when they say, "we find no compelling grounds for associating the tacit knowledge of either technologists or scientists necessarily with skills that are specific rather than 'generic' in their applicability." Knowledge of Chinese is surely a tacit skill, but one that reflects highly abstract knowledge with very general applicability. It is also far from idiosyncratic, being shared by something like a billion people.

The second point is that knowledge can be externalized and made less idiosyncratic in ways that do not necessarily involve codification. Knowledge is structure. And knowledge can thus be externalized beyond an individual creator by being imbedded either in machines and other physical technology or in various kinds of social or behavioral structures that I will broadly call institutions. These latter include imitable routines and skills; organizations; and abstract institutions like law, language, or culture. In discussing the historical sources of American economic growth, Gavin Wright (1999, p. 296) notes that technological knowledge "is not simply a body of abstract information, but is inherently social, embedded in

11 Compare Cowan and Foray (1997): “Typically, a piece of knowledge initially appears as purely tacit-a person has an idea. Often, though, as the new knowledge ages, it goes through a process whereby it becomes more codified. As it is explored, used, and better understood, less of it remains idiosyncratic to a person or few people, and more of it is transformed into some systematic form that can be communicated at low costs." 
terminology, in procedures, in physical equipment and in products." The nonconvexities that gave rise to growth in the United States arose from the increasingly national character of the "learning networks" that lay behind technological change. In effect, increased economic integration and labor mobility tended to standardize and generalize the country's knowledge-bearing institutions, permitting the knowledge they contained to be more widely reused and to be spread over more concrete applications. (I return to this theme below.)

The third point is that social institutions are often valuable precisely because and to the extent that they obviate the codification of knowledge. As Alfred North Whitehead remarked, it is "a profoundly erroneous truism, repeated by all copybooks and by eminent people when they are making speeches, that we should cultivate the habit of thinking what we are doing. The precise opposite is the case. Civilization advances by extending the number of important operations which we can perform without thinking about them"12 (Whitehead 1911, p. 61). Or, we might add, without describing them explicitly. To the extent that institutions embody knowledge, they make it less necessary for us to transmit information or acquire knowledge, codified or otherwise. Basketball players can execute such highly complex maneuvers as a fast break with only a minimal set of non-verbal signals. Similarly, professionals working in the same area of technology can often

12 As Whitehead adds: "Operations of thought are like cavalry charges in a battle -- they are strictly limited in number, they require fresh horses, andmust only be made at decisive moments." I am 
communicate insights and ideas with only minimal sets of signals. Well-functioning teams and organizations can operate effectively with no communication at all. Indeed, in such cases to observe a large amount of codified transmission would be evidence of less-effective knowledge structures - not evidence of "more" knowledge. ${ }^{13}$

\section{The reuse of know ledge.}

An important part of my argument here is that, because knowledge - even, or maybe especially, tacit knowledge - can be imbedded in institutions, we need to look to institutions for the sources of the nonconvexities that give rise to increasing returns and economic growth. That institutions partake of increasing returns is certainly well known (North 1990, p. 95). But what is the source of those increasing returns? ${ }^{14}$ I have argued elsewhere (Langlois 1999b) that increasing returns can in most cases be understood as instances of the reuse of knowledge.

indebted to both Brian Loasby and Bhaven Sampat for directing me to the original source of this quotation.

13 Cowan and Foray (1997) are right in pointing out that "it is in the context of change that we might find situations of excess codification." When the environment is changing, knowledge structures (whether tacit or codifying) are becoming less well adapted, leading to the generation and transmission of more codified information during the process of readaptation. This phenomenon is related to the "dynamic transaction costs" that can afflict organization in a world of rapid change (Langlois and Robertson 1995).

14 North (1990, pp. 94-95) cites four reasons that Brian Arthur (1988) had articulated in the context of technology: large set-up or fixed costs; learning effects; coordination effects; and adaptive expectations. The last three of these have obviously to do with knowledge. I argue below that even the notion of amortizing fixed set-up costs can be understood in terms of the reuse of knowledge. 
There are two mechanisms by which the reuse of knowledge can generate increasing returns, and both are driven by the extent of the market. The first is better appreciated: Smith's division-of-labor effect. The second is distinct and less often noticed; it is related to what I have called the "volume effect" (Langlois 1999a).

In the Smithian story, labor starts out unspecialized, in that each worker performs many different task; but each of the many tools the worker uses is specialized to a particular task. The division of labor consists in specializing labor to the same level as the already-specialized tools. This does not exhaust the possibilities, however. It is also possible, through mechanical innovation, for tools to become less specialized - to integrate previously separate tasks as the extent of the market grows (Ames and Rosenberg 1965; Robertson and Alston 1992). Transferring these tasks to machine embeds in the machine the knowledge of how to perform the tasks.

In drilling the plate A without the jig the skilled mechanic must expend thought as well as skill in properly locating the holes. The unskilled operator need expend no thought regarding the location of the holes. That part of the mental labor has been done once for all by the tool maker. It appears, therefore, that a "transfer of thought" or intelligence can also be made from a person to a machine. If the quantity of parts to be made is sufficiently large to justify the expenditure, it is possible to make machines to which all the required skill and thought have been transferred and the machine does not require even an attendant, except to make adjustments. Such machines are known as full automatic machines. (Kimball 1929, p. 26, emphasis original.)

As this quote from an old text on the organization of industry suggests, the transfer to a machine of "intelligence" archetypically takes the form of a jig, pattern, or die. 
And, as Alchian (1959) points out, the "method of production is a function of the volume of output, especially when output is produced from basic dies - and there are few, if any, methods of production that do not involve 'dies'" (Alchian 1959 [1977, p 282], emphasis added). Why? Because, with increased volume, it pays to invest in more durable dies.

Consider the example of printing. If one is going to run off a few copies of a memo, a photocopy machine will do the trick. If one needs several hundred copies of documents on an ongoing basis, it might be worth investing in a small offset press. For even larger predictable production runs, it would pay to have a more serious printing press. As volume and predictability allow greater "durability of dies," unit costs decline. This is an effect of growth in the extent of the market distinct from the division of labor narrowly understood. And the reason that costs decline as dies become more durable is not because the knowledge itself leaks out but because the knowledge — created once - is spread over more and more units.

The first mechanism of knowledge reuse - the Smithian division of labor also operates by imbedding knowledge rather than by transmitting it. But in this case the knowledge is imbedded in organizations and institutions rather than in technology. Smith's own account of the division of labor is very much about how (re)organization can yield increasing returns - about how knowledge can be imbedded in an organizational structure and, through standardization, can both 
substitute for and amplify the knowledge the individual workers possess (Leijonhufvud 1986; Langlois 1999a).

Notice that, in the case of organizations and institutions as in the case of technology, standardization is arguably the fundamental source of increasing returns. Here, however, it is behavior rather than physical technology that is standardized. Whether it is a classical Weberian bureaucracy (Mintzberg 1979) or an association as diffuse as a profession (Savage and Robertson 1999; Langlois and Savage 2000), the organization achieves coordination by standardizing the repertoire of routines its members possess. This is just as clearly true in the case of institutions, which, in a fundamental sense, are standards that orient behavior15 (North 1990). To take a simple example, the rule that one always drive on the right in the United States is an institution that allows us to coordinate our behavior with that of others by forcing us to reuse the same piece of knowledge over and over.

Perhaps the case of software will illustrate these points. In terms of embedded technology, software is the paradigm case of knowledge reuse through durable dies. Once written, a piece of code can be stamped out an indefinite number of times at little more than the marginal cost of burning a CD (Shapiro and Varian 1998). The idea of knowledge reuse, however, is generally associated with a somewhat different aspect of software production. Michael Cusumano (1991) argued that vertically

15 I am implicitly following North's (1990) distinction between institutions as the abstract rules of the game versus organizations as collective actors operating within the rules. In fact, however, the distinction is far more complex and blurry (Langlois 1995). 
integrated Japanese software houses may have advantages over decentralized American ones because the Japanese firms are better able to reuse portions of code written for earlier applications. Unlike American firms, Japanese firms can "remember" and don't have to start each new application from scratch. Notice that the increasing returns here arise in the context of economies of scope rather than of scale.16 Notice also, however, that the economies arise (a) from standardization and (b) within the context of organization. The function of memory is embedded in the Japanese firms in a way that it is (supposedly) not embedded in the American ones.

It turns out, however, that the "software factory" approach does not seem to have given Japanese firms anything like an advantage against American software developers. Rather the opposite is the case. The reason is that A merican firms have benefited from two other, more powerful, forms of standardization: standardized hardware platforms and object-oriented programming17 (Mowery 1995, p. 310). By reducing variety, the former reduced any economies-of-scope benefits the factory approach may have conveyed. And, by creating public standards, object-orientation pushed the reuse of knowledge from the organizational to the institutional realm, effectively creating external economies of scope (Langlois and Robertson 1995, p. 5).

16 Depending, of course, upon how narrowly one defines the product. Reuse of code gives economies of scope if it reduces the costs of producing different applications, but it gives economies of scale in the production of "more software."

17 Object-oriented programming involves a highly standardized and modularized form of codewriting that al lows programmers to assemble code easily from preexisting pieces much as a child assembles a structure out of building blocks. 


\section{Standardization and variety.}

Let me recast the argument a different way. Generality — the wide applicability and reusability of knowledge - is a source of increasing returns. But the limits to generality do not come from the tacitness of knowledge, since tacit knowledge can in fact be general. Moreover, all knowledge can be embedded in technology and institutions, and thus can be reused without being replicated qua knowledge through the Arrovian mechanism. What limits generality thus comes less from the supply side than from the demand side. That is, it is the demand for variety that, by limiting the possibilities for standardization, limits the reuse of knowledge. Bresnahan and Gambardella put it nicely.

An inherent tension in any division of labor is that the distinct users of a technology, or for that matter of a good or service, employ it for different purposes. Consequently, they have different needs, and these needs would be best satisfied by producing, adapting, or using the technology or input according to their special goals and demands. This is a force for localization. Standardizing the technology or input allows exploitation of the gains from specialization, while localizing it permits superior matching. A general specialty is a compromise between the scale economies inherent in specialization and the failure to localize inherent in generality ${ }^{18}$ (Bresnahan and Gambardella 1998).

The tradeoff is clear in the paradigm case of the reuse of knowledge through more durable dies. In order to spread the knowledge contained in the dies over more and more units, enough people must be willing to consume the identical products stamped out. As Henry Ford insisted, you can have any color Model T you want as

18 I discuss below what the authors mean by a "general specialty." 
long as it's black. Indeed, Alfred Marshall was one of the first of many to attribute American economic growth in the nineteenth and early twentieth centuries to "the homogeneity of the American demand for manufactured goods," which enabled standardization and mass production (Marshall 1920, I.viii.3, p. 146-7).

It is also possible, of course, to permit some variety while still reusing knowledge if the knowledge is applicable to more than one variant. In Cusumano's software-factory example, portions of code are reused in similar but not identical applications. General Motors pioneered an analogous strategy in the early automobile industry, using durable dies to stamp out standardized parts that went into a wide variety of slightly differentiated variant models (Raff 1991) - a classic American idea that Marshall (1920, I.viii.2, p. 141) called "multiform" standardization. This kind of "flexible specialization" need not belimited to physical technology. In the early part of this century, the American medical profession responded to the size and integration of the American market by standardizing medical training and medical record-keeping in a way that equipped individual practitioners with a standardized "toolkit" of routines but allowed them the flexibility to apply those routines to widely varying concrete circumstances Langlois and Savage 2000.

Using the terminology of George Stigler (1951), Bresnahan and Gambardella (1998) have called attention to the role in economic growth of "general specialties," al so called general-purpose technologies. A general specialty is a stage of production 
(specialized labor or tools) possessing knowledge or capabilities that are applicable to the production of many different outputs. Sometimes this is literally a technology, as in the case of the microprocessor, which, through software, can be adapted to many different uses. But the idea also presumably applies to knowledge more broadly, as in the case of American machine-tool capabilities in the early nineteenth century, which found application in a wide variety of mechanical industries (Rosenberg 1976, p. 16).

Very clearly, institutions can serve the same economies-of-scope function; they are also general-purpose technologies in this sense. The more abstract the institution, the more general its applicability, and the more widely can the knowledge it contains be reused and spread across different and varied outputs. As Hayek (1973, p. 50) has said, abstract institutions consist of "rules applicable to an unknown and indeterminable number of persons and instances." Examples surely include language, law, social conventions, and even culture more broadly. All involve pieces of knowledge shared across many individuals and uses. All are, in effect, standards.

The key difference between knowledge embodied in (standardizing) institutions and knowledge embodied in replicated artifacts is that the former allows greater variety in the ways the knowledge is reused. This is so because the standard creates a framework in which variety can in effect be created by the consumer. To see the point, consider the provision of variety in system products, complicated goods or 
services consisting of many interacting components and subsystems. For many such goods, variety can come in the form of multiple preassembled packages.

For instance, there are significant economies of scale in the assembly of cars; but, relative to the size of the market, those economies are exhausted early enough that many different firms can profitably offer consumers many different models, each a distinct system product. In this example, the benefits of standardization come entirely from the economies of scale in production they enable. But, in other cases, standardization can have additional benefits that come not from the supply side but from the demand side. These benefits arise from the much-discussed phenomenon of network effects: the benefits to any individual of a would-be standard depend on how many other individuals already adhere (or are likely to adhere) to that alternative. ${ }^{19}$ As more and more users commit to a standard, that standard becomes increasingly attractive to others; the commitment of those others makes the standard even more attractive - and so on in a cumulative fashion that is often described as "positive feedback." These are called network effects because, in the first instance, they arise in the case of physical connection networks like telephone systems. The value to me of a phone system increases with the number of other people who are on the system. But the concept has been applied to "virtual networks" in which the connections are not physical but rather in the nature of economic complementarity (Katz and Shapiro 1985). For example, the benefit to consumers of a new digital

19 For recent surveys, see David and Greenstein (1990) and Economides (1996). 
television standard is proportional to the amount of programming they expect to be available on that standards, which is in turn dependent of the number of people who adopt the standard.

The dominance of a single standard may have its costs in foregone variety. Imagine a world in which manufacturers were all required to produce identical generic "people's cars" the parts for which were all standardized and interchangeable. Although there would likely be intense competition within the system by parts suppliers and assemblers, probably leading to significant modular innovation (Langlois and Robertson 1992), the benefits of the standard would likely be outweighed by the costs in lost variety. Of course, saying that parts are interchangeable doesn't mean that they are all identical, and cars could be differentiated by the parts they use rather than by the overall design. To take a trivial example, one could plug in a high-quality car stereo system as easily as a lowquality one. But, in the case of automobiles, the fact of economies of scale in assembly and the lack of demand-side network effects suggest that variety is probably best provided in preset packages.

In many other systems, however, this is not the case. When there are low economies of scale in assembling a system, a modular structure, in which variety is provided through the choice of modules, can more thoroughly blanket the product space, and can do so in virtually a perfectly discriminating way (Langlois and Robertson 1992). This point applies a fortiori to so-called hardware-software 
networks in which the "modules" are in the nature of software. Indeed, as a rough approximation, we might say that there is less of a tradeoff between variety and standardization the greater the extent to which variety is a matter of "software" rather than "hardware."

In part, this is a reflection of our perspective within the hierarchy of systems. Even if there are economies of scale in assembling major components of the system, there may not be economies of scale in offering variety in the system as a whole. For example, there are economies of scale in assembling televisions and videocassette recorders. But there are no such economies to hooking those components together and playing one of a wide variety of available tapes. Similarly, there are economies of scale in packaging variety in cars, but lower economies in packaging variety in the wider transportation system, since travel to different destinations using complementary modular assets like roads is a source of variety. N otice that, in both cases, it is the software rather than hardware - the tapes in one case and the destinations in the other - that creates much of the variety in the larger system. Of course, cars and (perhaps a lesser extent) video hardware nonetheless continue to provide some element of the variety, since different hardware can interact with the software to produce slightly different experiences. Driving through the Berkshires in a Porsche is not the same as driving there in a Chevy; watching Star Wars on a widescreen TV is not the same as watching it on a 19-inch screen. In the case of personal computers, however, even the hardware can be varied by recombining modules. 
These observations generalize from technological standards to standards qua institutions more generally. Although there would surely be a loss of variety in some sense if we were all to speak only one language, yet that one language would be capable of generating an infinite variety of "software." I can enjoy just as many destinations if I have to drive on the left and if green means stop. And inhabitants of the same "learning network" -- to recall Wright's term - can generate a limitless variety of innovations.

\section{Consumption.}

The "demand side" has entered our story so far only in a rather negative way. By craving variety, consumers reduce the ability of producers to standardize products and thus to spread knowledge overheads through embodiment in output. Two remarks are in order, however. First, consumers of intermediate goods (who are themselves producers and not final consumers) can also crave variety to the extent that similar outputs are produced in different ways in different places. Second, modern consumption theory sees even final consumers as producers who cobble together basic utility from various inputs (Lancaster 1971, Stigler and Becker 1977). Thus much of what I argued above applies easily to final consumption as well, even if there remain a few twists and turns.

Metin Cosgel and I have suggested that, although we should readily embrace the simile of consumption as production, we ought, however, to change our picture of how consumption is produced (Langlois and Cosgel 1998). Rather than taking on 
board the conventional production-function approach, we should apply instead the theory of economic capabilities that is gaining currency in the theory of the firm (Teece and Pisano 1994; Langlois and Robertson 1995. In this view, the "production" knowledge required for consumption is not explicit and given, not contained in the mythical blueprints of neoclassical price theory. Instead, such knowledge is a matter of consumption routines, often tacit and acquired at a cost. As in the theory of the firm, one of the central issues in this revised theory of consumption is one of boundaries, that is, what kinds of routines will be generated within the consumption unit (the household) and what kinds imported from without? In light of our concerns here, we can recast the question thus: what are the possibilities for knowledge reuse in the household, and what are their implications for economic growth?

The problem of knowledge on the consumption side is not entirely a new concern. Four score and seven years ago, Wesley Clair Mitchell pondered the problems of knowledge and organization in consumption. "Important as the art of spending money is," he wrote, "we have developed less skill in its practice than in the practice of making money" (M itchell 1912, p. 269). It may shed considerable light on our themes to examine with hindsight Mitchell's analysis of the problem of consumption and his predictions for how economic growth would interact with that problem. 
The wellspring of Mitchell's analysis is the observation that final consumption is necessarily crafts production. Because the final consumer must buy or produce internally a wide variety of items and services in small batches, its is never cost effective to use either high-volume machinery or the division of labor to any significant extent. If shopping "could betaken over for many families and conducted by a business enterprise it would be subdivided into several departments, and each department would have its own minute division of labor" (p. 272). But this is not possible within a single household. Mitchell is similarly pessimistic about the use of large-scale machinery. "The family unit is so small, the tasks are so various, and the housework is so scattered from cellar to attic as to make machinery more troublesome than useful. ... Hence the equipment which can be employed economically in the household falls into the class of inexpensive utensils and hand tools; even in this age of steam and electricity, a family must be cared for by hand" (p. 272).

Two other problems plague household consumption in Mitchell's account. The first is that, unlike a business, a household cannot avail itself of the latest in scientific (codified?) knowledge. This is not merely because of the crafts character of household production but because consumption (or family management, at any rate) relies more on sciences like psychology and physiology, which (in Mitchell's' view) are backward in comparison with the physical and chemical sciences of use to industry. "Until such time as science shall illuminate the housewife's path, she must 
walk in the twilight of traditional opinion" (p. 276). The second impediment to household production is that, unlike a business, a household cannot use money as a common denominator to allocate resources internally. The benefits of the price system - a crucial knowledge-economizing institution - are limited to the household's interactions with the market.

What are Mitchell's' prescriptions to solve the dilemmas of consumption? On the whole he is pessimistic, as he (rightly) sees the desire for privacy and the durability of the nuclear family as militating against a non-crafts form of household production. But he does see two possible areas of productivity improvement: (1) communal consumption in order to share overheads and divide labor and (2) improving the capabilities of consumers through the progress and dissemination of science and through increased education of consumers.

Among the examples of communal consumption Mitchell has in mind are apartment buildings, "with their steam heat, janitor services, and common washtubs" (p. 280), as well as something called the family hotel, which was presumably a kind of boarding house that catered to families. He also cites various kinds of public facilities like "playgrounds, parks, library stations, day-nurseries - a socialized spending of money with a neighborhood instead of a family as unit" ( $p$. 280). It is interesting that Mitchell never seems to think of the market as a source of communal consumption. 
Mitchell is more sanguine about the beneficial effects of new knowledge directly imbibed by households. "With greater confidence we may rely upon progress in physiology and psychology to make wider and more secure the scientific foundations of housekeeping" (p. 280). This knowledge, he feels, will be readily disseminated by popular magazines and women's clubs. "Probably of more importance will be the growing attention to 'domestic science' in the schools, and the efforts of colleges and universities to meet the popular demand for adequate instruction in the matters of gravest import to future wives and mothers" (p. 280). He even suggests the possible emergence of a profession of Doctors of Domestic Science, who would serve a function somewhere between consultancy and social work.

In its analysis of the problem of consumption, Mitchell's essay holds up well. Consumption remains very much crafts production. Indeed, with the passing of the traditional female role, there is arguably less division of labor in the household today than there was in Mitchell's time. And, although we now have innumerable gadgets Mitchell could never have imagined - from food processors and microwaves to vacuum cleaners and clothes dryers - these innovations are improvements in the tools of a craft, not integrated large-scale machines employing durable dies.

In his prognostications, Mitchell has perhaps fared less well. Far from witnessing increased communal consumption, the last 87 years have seen a secular decline in it. Privacy is a normal good, and, with rising incomes, people have craved 
more. This, along with the automobile, abundant land, and favorable government policies in the United States, has led to the widespread ownership of single-family homes - all despite the prospect of common washtubs. And, much to the dismay of innumerable social commentators over the years, technological changes have also made other consumption activities more private.20 Television comes to mind.

In a crucial sense, however, present-day consumers do rely on more "collective" consumption that did their forebears in Mitchell's day. But the shared overheads from which they benefit come to them through the market, in many ways the most "collective" of all social institutions. Mitchell understood this phenomenon early in his essay, when he notes that people in more primitive times and on the frontier needed to make for themselves products we can now rely on others for. But Mitchell writes as if this margin disappeared once people stopped spinning their own wool and building their own furniture. In fact, the margin is alive and well. When we take the kids to daycare, order Chinese, or call in a cleaning company or a caterer, we are outsourcing in much the same way an industrial concern might outsource. $^{21}$ And we do it for the same reasons.

There is also another mechanism through which we benefit as consumers from the increasing returns available in the market. Just as the factory system took

20 Even when people today consume collectively - as when they attend rock concerts or sporting events - they do not do so to share overheads or reduce costs. Quite the opposite. The collective character of such consumption is simply another (sometimes) valuable characteristic of the good, which could otherwise have been provided more cheaply in a private fashion. 
advantage of unskilled labor by embodying knowledge in organizational structure, so too producers (and sometimes consumers themselves) can compensate for the lack of consumer capabilities by embodying knowledge in products and services and in consumption institutions. The TV dinners and redimix cakes of the 50 s have long since attained the status of cultural icons. With prepackaged and tested medicines, consumers today can attain better health outcomes than Mitchell's contemporaries with arguably a smaller stock of knowledge about physiology. Chain stores and large-scale markets reduce search costs by allowing customers to reuse their knowledge about where to find things. ${ }^{22}$ Indeed, we can think of large-scale outlets like Walmart as modular consumption systems that allow buyers to assemble variety at low cost.

Thus, far from having gained greater training in the domestic arts, consumersas-producers have become "deskilled" by knowledge embodied in products and institutions. Given also the high opportunity cost of any specialization in "homemaking" in an advanced economy, it is not surprising that the market for instruction in domestic skills has tanked. What was once Home Economics at my university is now the Department of Design and Resource Management, and it caters more to varsity athletes seeking acceptable grades than to prospective homemakers.

21 In the United States, daycare is typically provided through the market rather than through the communal day-nurseries Mitchell envisaged.

22 Of course, to the extent that shopping conveys utility directly, consumers may prefer more "artisinal" shopping, which explains the popularity of boutiques. 
This does not mean, however, that there is no role for learning by consumers themselves. There are still arguably "learning networks" in consumption, even if they no longer manifest themselves through women's clubs. People with similar inclinations - whether it be child rearing, computers, or skiing - gather together in informal networks to share information and experiences. Moreover, if we take the view that consumption knowledge is a matter of learned routines, then other institutions of consumer learning appear in unexpected places. Mitchell mentions the phenomenon of conspicuous consumption popularized by his contemporary Veblen, apparently viewing such behavior as an inefficient manifestation of the difficulty of allocating resources in the absence of a rational common denominator like money. But if consumption knowledge is costly and embedded in routines, we might actually wonder whether keeping up with the Joneses, and maybe even aspects of conspicuous consumption itself, may not reflect the rational imitation of successful consumption routines observed in others. Following fashion can have the effect of standardizing consumption routines, even if rapid changes in fashion have the opposite effect.

The issue of change returns us to the topic of knowledge as structure. The assembled routines of consumers are a knowledge structure that, to be effective, must be compatible with other knowledge structures in society. In this case, the routines of consumers must mesh with those of producers (Langlois and Cosgel 1998). In the long run this is not much of a problem, as each side has the incentive to 
adapt to the other. In the short run, however, major technological changes in the routines of consumption or (perhaps more typically) of production may necessitate major changes on the other side. Sometimes these changes are far from traumatic. Consumers arguably adapted easily to the introduction of branded packaged goods in the nineteenth century, even though these eliminated the role of intermediaries (like the butcher or the keeper of the general store) in measuring quantity and assuring quality (Chandler 1977). But the change from mainframe computers to the decentralized client-server technology in the 1990s required a much more dramatic change in the routines of users, one that Bresnahan and Greenstein (1997) go so far as to label "coinvention."

\section{G rowth.}

At the American Economic Association meeting three years ago, Paul Romer described the worldview of the New Growth Theory this way.

New growth theorists now start by dividing the world into two fundamentally different types of productive inputs that can be called "ideas" and "things." Ideas are nonrival goods that could be stored in a bit string. Things are rival goods with mass (or energy). With ideas and things, one can explain how economic growth works. Nonrival ideas can be used to rearrange things, for example, when one follows a recipe and transforms noxious olives into tasty and healthful olive oil. Economic growth arises from the discovery of new recipes and the transformation of things from low to high value configurations (Romer 1996, p. 204).

I have tried here to take the contrary position that (1) this distinction is not true to the world and (2) it is not necessary to explain economic growth. 
Knowledge often lives in things themselves, and just as often in the interstices between things and bit strings. These interstices are institutions. Growth is indeed about increasing returns, about the nonconvexities that arise when knowledge is produced once then reused many times. But the mechanism of knowledge reuse does not al ways - and perhaps does not mostly — involve knowledge transmission. Instead, the knowledge is reused by being imbedded in technology, organizations, and institutions. Although private rent-seeking behavior surely drives the engine, the process of knowledge creation is a social one, a kind of spontaneous order that arises not mostly from the directed search for knowledge but from the unintended effects of production and consumption. Knowledge creation is unmistakably endogenous to the economic process. But if we try to overlay a production function on this process, it would have to look more like the manna of an exogenous $\lambda$ parameter than the result of rational optimizing behavior aimed at its creation. This is far from saying that we can't theorize about the process of knowledge creation and its role in economic growth. We have a lot of pieces of that theory. But they are not lying under the production-function lamppost.

"If new growth theorists have their way," writes Romer (1996, p. 206), "the first distinction economists will draw when looking at the physical world will be the one that separates rival things from nonrival ideas." If I have my way - admittedly, a far less likely possibility - economists will realize that things and ideas cannot be separated. 


\section{References.}

Alchian, Armen A .. 1959. "Costs and Output," in Moses Abramovitz et al., eds., The Allocation of Economic Resources. Stanford: Stanford University Press, reprinted in idem., Economic Forces at W ork. Indianapolis: Liberty Press, 1977.

Ames, Edward, and Nathan Rosenberg. 1965. "The Progressive Division and Specialization of Industries," Journal of D evelopment Studies 1(4): 363-383 (July).

Arora, A shish, and Alfonso Gambardella. 1994. "The Changing Technology of Technological Change: General and Abstract Knowledge and the Division of Innovative Labour," Research Policy 23(5): 523-532 (September).

Arrow, Kenneth J. 1962. "Economic Welfare and the Allocation of Resources to Invention," in Richard. R. Nelson, ed., The Rate and D irection of Inventive Activity: Economic and Social Factors. Princeton: Princeton University Press.

Arrow, Kenneth J. 1974. The Limits of Organization. New York: W. W. Norton.

Arthur, W. Brian. 1988. "Self-Reinforcing Mechanisms in Economics," in Philip W. Anderson, Kenneth J. Arrow, and David Pines, eds., The Economy as an Evolving Complex System. Reading, MA: Addison-Wesley.

Boisot, Max H. 1995. Information Space: A Framework for Learning in Organizations, Institutions, and Culture. London: Routledge.

Boulding, Kenneth E. 1955. "Notes on the Information Concept," Explorations [Toronto] 6 : 103-112.

Bresnahan, Timothy F., and Alfonso Gambardella. 1998. "The Division of Inventive Labor and the Extent of the Market," in Elhanan Helpman, ed., General Purpose Technologies and Economic Growth. Cambridge: MIT Press.

Bresnahan, Timothy F., and Shane Greenstein. 1997. "Technical Progress and Co-invention in Computing and the Use of Computers," in Martin Neil Bailey, Peter C. Reiss, and Clifford Winston, eds., Brookings Papers on Economic Activity: M icroeconomics, 1996. Washington, DC: Brookings Institution.

Chandler, Alfred D., Jr. 1977. The V isible H and. Cambridge: The Belknap Press of Harvard University Press.

Cowan, Robin, and Dominique Foray. 1997. "The Economics of Codification and the Diffusion of Knowledge," Industrial and Corporate Change 6(3): 595-622 (September).

Cowan, Robin, Paul A. David, and Dominique Foray. 1999. "The Explicit Economics of Knowledge Codification and Tacitness," Working Paper 99-027, Stanford University. 
Cusumano, Michael A. 1991. Japan's Software Factories: A Challenge to U S. M anagement. New York: Oxford University Press.

Dasgupta, Partha, and Paul A. David. 1994. "Toward a New Economics of Science," Research Policy 23(5): 487-521.

David, Paul A., and Shane Greenstein. 1990. "The Economics of Compatibility Standards: An Introduction to Recent Research," Economics of Innovation and N ew Technology 1(12): 3-41.

Dreyfus, Hubert L. 1979. What Computers Can't D o: The Limits of Artificial Intelligence. New York: Harper Colophon, revised edition.

Dutton, Harold I. 1984. The Patent System and Inventive A ctivity during the Industrial Revolution, 1750-1852. Manchester: Manchester University Press.

Economides, Nicholas. 1996. “The Economics of Networks," International Journal of Industrial O rganization 14(2): 675-699.

Edelman, Gerald M. 1987. N eural D arwinism: the Theory of N euronal Group Selection. New York: Basic Books.

Edelman, Gerald M. 1992. Bright Air and Brilliant Fire: O $n$ the M atter of M ind. New York: Basic Books.

Hayek, F. A. 1952. The Sensory O rder: A n Inquiry into the Foundations of Theoretical Psychology. Chicago: The University of Chicago Press.

Hayek, F. A. 1973. Law, Legislation and Liberty. Chicago: University of Chicago Press, Volume I.

Hayek, F. A. 1978. N ew Studies in Philosophy, Politics, Economics, and the History of Ideas. Chicago: The University of Chicago Press.

Holland, John H., Keith J. Holyoak, Richard E. Nisbett, and Paul R. Thagard. 1986. Induction: Processes of Inference, Learning and Discovery. Cambridge: MIT Press.

Grossman, Gene M., and Elhanan Helpman. 1991. "Trade, Knowledge Spillovers and Growth," European Economic Review 35(3): 517-526 (May).

Grossman, Gene M., and Elhanan Helpman. 1994. “Endogenous Innovation in the Theory of Growth," Journal of E conomic Perspectives 8(1): 23-44 (Winter).

Katz, Michael, and Carl Shapiro. 1985. "Network Externalities, Competition, and Compatibility," A merican Economic Review 75(3): 424-440.

Kimball, Dexter S. 1929. Industrial Economics. New York: McGraw-Hill. 
Lamoreaux, Naomi R., and Kenneth L. Sokoloff. 1999. "Inventive Activity and the Market for Technology in the United States, 1840-1920," NBER Working Paper No. W7107.

Lancaster, Kelvin. 1971. Consumer Demand: A N ew A pproach. New York: Columbia University Press.

Langlois, Richard N. 1995. “Do Firms Plan?” Constitutional Political Economy 6(3): 247-261.

Langlois, Richard N. 1997. “Cognition and Capabilities: Opportunities Seized and Missed in the History of the Computer Industry," in Raghu Garud, Praveen Nayyar, and Zur Shapira, eds., Technological Innovation: Oversights and Foresights. New York: Cambridge University Press.

Langlois, Richard N. 1999a. "The Coevolution of Technology and Organization in the Transition to the Factory System," in Paul L. Robertson, ed., A uthority and Control in M odern Industry. London: Routledge.

Langlois, Richard N. 1999b. "Scale, Scope, and the Reuse of Knowledge," in Economic Organization and Economic Knowledge: Essays in Honour of Brian J. Loasby, Volume I. Cheltenham: Edward Elgar.

Langlois, Richard N., and Paul L. Robertson. 1992. "Networks and Innovation in a Modular System: Lessons from the Microcomputer and Stereo Component Industries," Research Policy 21(4): 297-313.

Langlois, Richard N., and Metin M. Cosgel. 1998. "The Organization of Consumption," in Maria Bianchi, ed., The A ctive Consumer. London: Routledge, pp. 107-121..

Langlois, Richard N., and Paul L. Robertson. 1995. Firms, M arkets, and Economic Change: A Dynamic Theory of Business Institutions, London: Routledge.

Langlois, Richard N., and Paul L. Robertson. 1996. "Stop Crying over Spilt Knowledge: A Critical Look at the Theory of Spillovers and Technical Change," paper presented at the MERIT conference on Innovation, Evolution and Technology, A ugust 25-27, 1996, Maastricht, the N etherlands.

Langlois, Richard N., and Deborah A. Savage. 2000. "Standards, Modularity, and Innovation: the Case of Medical Practice," in Raghu Garud and Peter Karnøe, eds., Path Creation and D ependence Hillsdale, MI: Lawrence Erlbaum Associates.

Leijonhufvud, Axel. 1986. "Capitalism and the Factory System," in R. N. Langlois, ed., Economics as a Process: Essays in the N ew Institutional E conomics. New York: Cambridge University Press.

MacKay, Donald M. 1969. Information, M echanism, and M eaning. Cambridge: MIT Press. 
Machlup, Fritz. 1983. "Semantic Quirks in Studies of Information," in Fritz Machlup and Una Mansfield, eds., The Study of Information: Interdisciplinary M essages, New York: John Wiley, pp. 641-671.

Marshall, Alfred. 1920. Industry and Trade. London: Macmillan, Third Edition.

Mintzberg, Henry. 1979. The Structuring of O rganizations. Englewood Cliffs: Prentice-Hall.

Mitchell, Wesley C. 1912. "The Backward Art of Spending Money," A merican Economic Review 2(2): 269-282 (June).

Mowery, David C. 1995. "Conclusion," in David C. Mowery, ed., The International Computer Software Industry: A Comparative Study of Industry Evolution and Structure. New York: Oxford University Press.

Nelson, Richard R. 1992. “What Is 'Commercial' and What Is 'Public' about Technology, and what Should Be?" in Nathan Rosenberg, Ralph Landau, and David C. Mowery, eds., Technology and the W ealth of $\mathrm{N}$ ations. Stanford: Stanford University Press, pp. 57-71.

Nelson, Richard R., and Sidney G. Winter. 1982. An Evolutionary Theory of Economic Change. Cambridge: Harvard University Press.

North, Douglass C. 1990. Institutions, Institutional Change, and Economic Performance. New York: Cambridge University Press.

Polanyi, Michael. 1958. Personal Knowledge. Chicago: University of Chicago Press.

Raff, Daniel. 1991. "Making Cars and Making Money in the Interwar Automobile Industry: Economies of Scale and Scope and the Manufacturing behind the Marketing," Business H istory Review 65(4): 721-753.

Robertson, Paul L., and Lee J. Alston. 1992. "Technological Choice and the Organization of Work in Capitalist Firms," Economic H istory R eview 45(2): 330-49 (May).

Romer, Paul M. 1986. "Increasing Returns and Long-Run Growth," Journal of Political Economy 94: 1002-1037.

Romer, Paul M. 1990 “Endogenous Technological Change,” Journal of Political Economy 98: S71-S102.

Romer, Paul M. 1996. “Why Indeed in America? Theory, History and the Origins of Modern Economic Growth," A merican Economic Review 86: 202-206.

Rosenberg, Nathan. 1976. Perspective on Technology. New York: Cambridge University Press.

Savage, Deborah A., and Paul L. Robertson. 1999. "The Maintenance of Professional Authority: The Case of Physicians and Hospitals in the United States," in Paul L. Robertson, ed., A uthority and Control in M odern Industry, London: Routledge. 
Saviotti, Pier Paolo. 1998. "On the Dynamics of Appropriability, of Tacit and Codified Knowledge," Research Policy 26: 843-856.

Shapiro, Carl, and Hal R. Varian. 1998. Information Rules: A Strategic Guide to the Network Economy. Boston: Harvard Business School Press.

Smith, Adam. 1976. An Enquiry into the $N$ ature and Causes of the W ealth of $N$ ations. Glasgow edition. Oxford: Clarendon Press.

Solow, Robert M. 1956. "A Contribution to the Theory of Economic Growth," Quarterly Journal of Economics 70(1): 65-94 (February).

Stigler, George J. 1951. "The Division of Labor Is Limited by the Extent of the Market," Journal of Political Economy 59(3): 185-193.

Stigler, George, and Gary Becker. 1977. "De Gustibus Non Est Disputandum," A merican Economic Review 6: 76-90.

Swan, T. W. 1956. “Economic Growth and Capital Accumulation," Economic Record 32: 334 61.

Teece, David J., and Gary Pisano. 1994. "The Dynamic Capabilities of Firms: an Introduction," Industrial and Corporate Change 3(3): 537-556.

Weimer, W. B. 1982. "Hayek's A pproach to the Problems of Complex Phenomena: An Introduction to the Psychology of the Sensory Order," in W. B. Weimer and D. Palermo, eds., Cognition and the Symbolic Processes. Volume II. Hillsdale: Lawrence Erlbaum.

Whitehead, Alfred North. 1911. An Introduction to M athematics. New York: Henry Holt and Company.

Wright, Gavin. 1999. "Can a Nation Learn? American Technology as a Network Phenomenon," in Naomi R. Lamoreaux, Daniel M. G. Raff, and Peter Temin, eds., Learning by Doing in M arkets, Firms, and Countries. Chicago: University of Chicago Press, pp. 295-326. 